\section{Large lipoma of the larynx and its removal using a laryngofissure approach: Case report}

Ognjen Cukic ${ }^{1}$, Sanja Nikolic ${ }^{1}$, Milan B. Jovanovic ${ }^{1,2}$ ${ }^{1}$ Clinic of Otorhinolaryngology with Maxillofacial Surgery, Clinical Hospital Center Zemun

${ }^{2}$ Medical Faculty, University of Belgrade, Serbia

\section{Abstract}

Laryngeal lipomas are a rare form of a benign mesenchymal tumour containing fatty tissue. They can occur at any subcutaneous location part of the body, particularly in the trunk and lower and upper limbs where fat tissue is more abundant. We present the case of a 66-year-old man complaining of long lasting (3 years) discomphort in his throat, with no breathing or glutition problems. CT scans showed a $3.0-\mathrm{cm}$ fat-containing mass involving the left aryepiglottic fold. The patient was taken to the operating room for excision of the mass using a laryngofissure approach. The final pathologic diagnosis was lipoma. We describe a case of large laryngeal lipoma removed through an external surgical approach in order to prevent any possible recurrence or malignant alteration.

Key words: lipoma, aryepiglottic fold, laryngofissure

\section{Large lipoma of the larynx and its removal using a laryngofissure approach: Case report}

Ognjen Cukić ${ }^{1}$, Sanja Nikolić ${ }^{1}$, Milan B. Jovanović ${ }^{1,2}$ ${ }^{1}$ Clinic of Otorhinolaryngology with Maxillofacial Surgery, Clinical Hospital Center Zemun

${ }^{2}$ Medical Faculty, University of Belgrade, Serbia

\title{
Apstrakt
}

Laringealni lipomi su retke forme benignih mezenhimalnih tumora masnog tkiva. Mogu se pojaviti na brojnim podkožnim lokalizacijama, a posebno u delovima tela koja su bogata masnim tkivom. Prikazujemo slučaj 66-godišnjeg pacijenta muškog pola koji se žalio na dugotrajni (3 godine) neprijatan osećaj u grlu bez poremećaja gutanja i disanja. CT sken je pokazao tumorsku masu prečnika $3 \mathrm{~cm}$ koja je zahvatala levi ariepiglotisni nabor. Pacijentu je učinjena ekscizija tumora laringofisuralnim pristupom. Definitivna patološka dijagnoza je lipom. Opisujemo slučaj ogromnog laringealnog lipoma koji je uklonjen spoljašnjim hirurškim pristupom kako bi se sprečilo eventualno nastajanje recidiva ili maligne alteracije.

Key words: lipom, ariepiglotisni nabor, laringofisura

\section{Introduction}

Lipomas are benign tumours of adipose tissue. Although being the commonest neoplasms of mesenchymal origin, they seldom appear in the upper aerodigestive tract region (larynx, hypopharynx), representing only $0.6 \%$ of all benign tumours [1]. Their peak incidence occurs during the fifth and sixth decades of life. Lipoma of the larynx is more frequent in males $(62,5 \%)$ [2]. Usually encapsulated and solitary, its long asymptomatic course makes the diagnosis difficult. We present the case of a patient with lipoma of the left aryepiglottic fold, which we were able to remove using an open approach - a laringofissure.

\section{Case report}

A 66-year old male was referred to Zemun Clinical Centre Otorhinolaryngology Office, complaining of foreign body sensation in his throat during the past three years, but without breathing or swallowing difficulties. Clinical examination revealed a 3 -centimeter round growth with smooth, yellowish surface in the region of the left hemilarynx. CT scan confirmed homogenous, well-defined fat containing mass of the left hemilarynx (Figure 1.A.). Laryngomicroscopy and the examination of larynx by angled telescopes in general anaesthesia revealed broad based multilobular submucosal mass, originating from the left aryepiglottic fold. (Figure 1.B.). 


\section{CASE REPORTS}

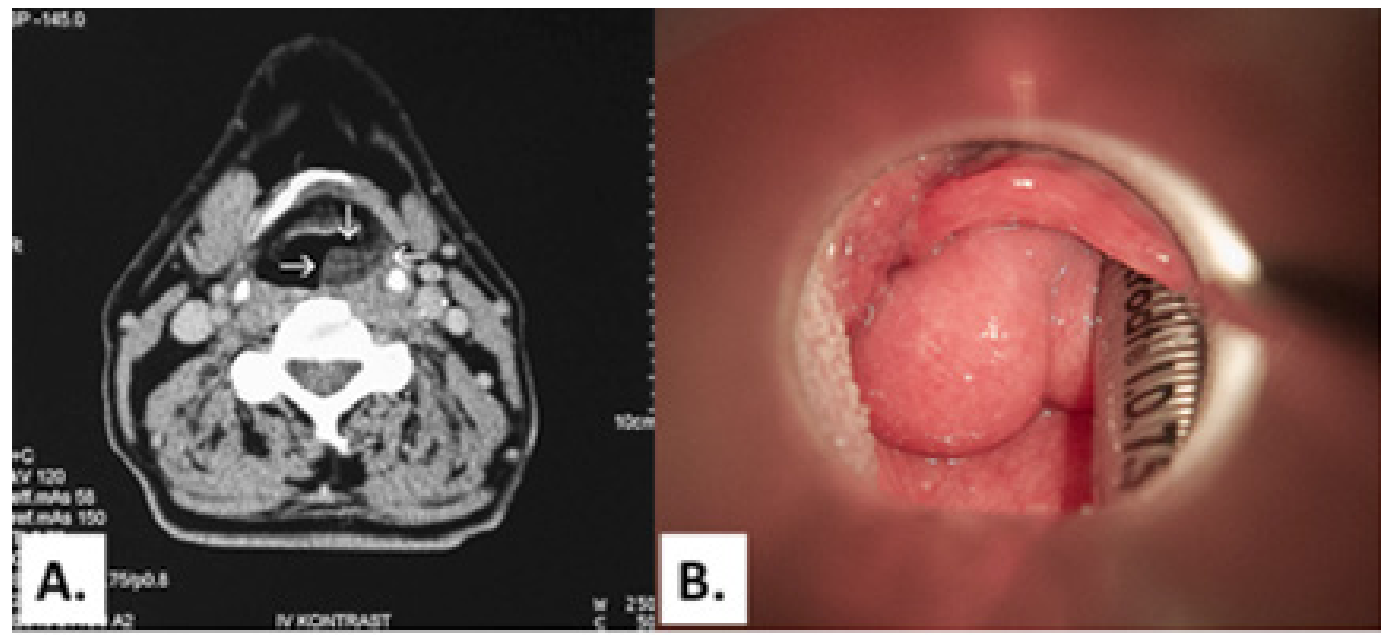

Figure 1. A homogenous and well-defined encapsulated mass of the left hemilarynx; B. Laryngomicroscopic view of the mass

Given its size and localization, the mass was completely removed using external access through laringofissure (Figure 2.A). Tumor was not adherent to the surrounding tissue and could be completely removed with sharp dissection. The excised tumor measured $3 \mathrm{~cm}$ in maximum diameter (Figure 2.B). The histopathology showed features of lipoma. The nasogastric tube was not inserted and oral liquid feeding was initiated 3 days after surgery. Recovering of patient was successful and there were no symptoms of any postoperative nerve injury. One year later, the check-up did not show any recurrence of the disease.

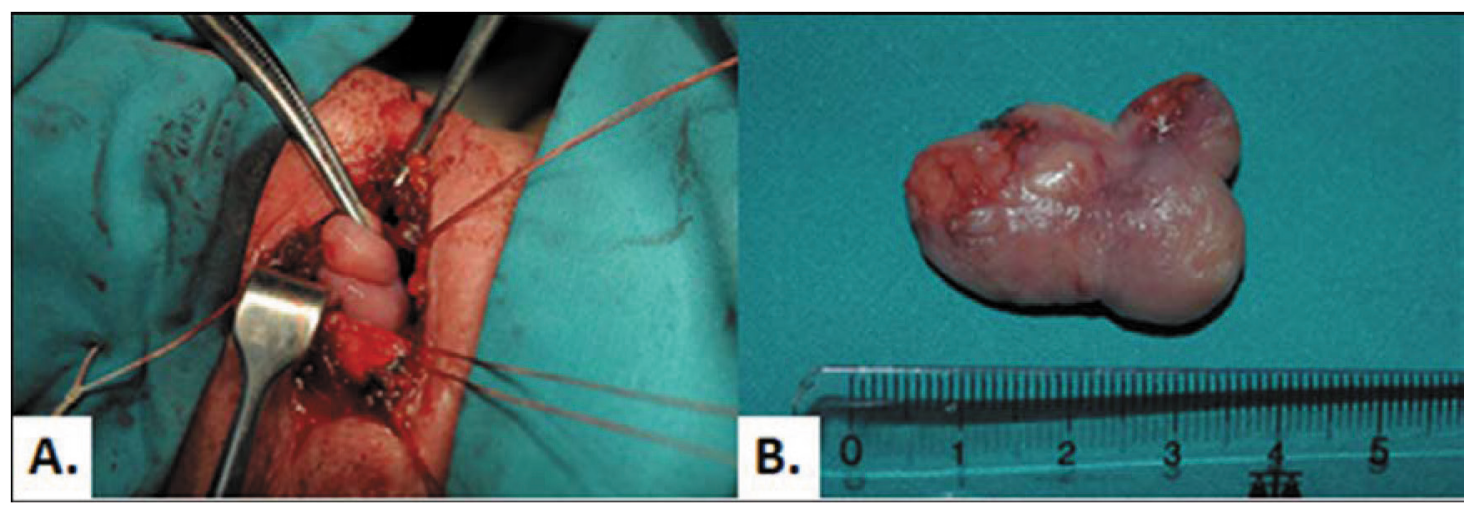

Figure 2. A. Laryngofissure and exposure of the mass; B. Macroscopic appearance of removed mass

\section{Discussion}

Lipomas of the larynx are a rare clinical entity and are usually asymptomatic. When present, symptoms rise due to mechanical compression of lipoma on the surrounding anatomical structures. Patients usually complain of non-specific symptoms, such as dysphagia, hoarseness, throat discomfort and dyspnoea ${ }^{3,4}$. The most serious complication is an airway obstruction due to the prolapse of a large pedunculated lipoma in the laryngeal lumen, ${ }^{5}$ thus necessitating urgent tracheotomy, with several cases of asphyxia described ${ }^{6,7}$. A typical clinical finding is a smooth, yellowish mass with a wide or narrow base. They usually occur singly; only $5 \%$ arise in multiple sites. In the latter situation, they can represent the clinical manifestation of different diseases and syndromes ${ }^{8}$. To date, no definite etiological factors have been identified. It was suggested that lipomas could arise from embryogenetic lipoblast cells or metaplastic muscle cells ${ }^{9}$. Others mentioned a possible aetiopathogenetic role of familial and endocrine factors, trauma, infections or chronic irritating 
conditions ${ }^{10}$. Further, cytogenetic changes have been found characterized by monosomy or partial loss of chromosome13 and/or $16^{11}$. The preoperative imaging is obtained by using the computerised tomography or magnetic resonance imaging. MRI is superior to CT in terms of better soft definition, as well as avoidance of patient exposure to ionizing radiation and iodine contrast agents ${ }^{12}$. Given the size of the tumour we present, its base was confirmed with angled Hopkins telescope. Upon endoscopic (and CT examination) tumour we present appeared as an encapsulated, sessile retention-cyst-like mass, covered by pinkish-yellowish normal mucosa. Usually size may vary from a few millimetres to one centimetre. Our lesion, which was fairly large, originated from the left aryepiglottic fold and extended superiorly involving the hypopharynx and partially filling the left piriform fossa. Despite its size, the mass did not compromise the laryngeal airway. Lipoma often presents a thin fibrous capsule and the mature adipose tissue is subdivided into lobules by a meshwork of fibrous strands. Surgical approach is determined by several characteristics of the tumour, such as its site, size, vascularity and potential malignancy. The mass is usually removed through the suspension laryngoscopy, which is true for smaller lipomas with a narrow pedunculated base. Larger lipomas with a wide base require an open approach. Some surgeons advocate lateral pharyngotomy ${ }^{13}$, while we decided to use the laryngofissure approach. In our case, laryngofissure approach provided excellent exposure of the mass, allowing complete en-bloc removal, while carefully preserving the vocal ligament.

Malignancy should be suspected in patients with multiple or recurrent laryngeal lipoma ${ }^{14}$. Postoperatively, the patient did not require the feeding tube or temporary tracheostomy. Although rare, these lesions should be considered in differential diagnosis of the laryngeal masses. The CT findings facilitated planning of the treatment strategy. Complete surgical removal is the treatment of choice, having in mind the possibility of acute airway obstruction and concomitant asphyxia. The presented case of laryngeal lipoma removal using an external surgical approach demonstrated that the laryngofissure is adequate for complete surgical removal. Extended period of long-term follow up is essential as lipomas are usually recurrent and potentially malignant.

\section{References}

1. Barnes L, Ferlito A. Soft tissue neoplasms. In: Ferlito A, editor. Neoplasms of the larynx. First edition. London:ChurchillLivingstone; 1993. p. 265-304.

2. El-Morem MH, Gaafar AH, Magdy EA. Lipomas of the head and neck: presentation variability and diagnostic workup. J Laryngol Otol. 2006 120(1):47-55.

3. D, Antonio A, Mottola G, Caleo A, Addesso M, Boscaino A. Spindle cell lipoma of the larynx. Ear Nose Throat J. 2013 92(6):E9-E11.

4. Barry B, Charlier JB, Ameline E, et al. Retro-pharyngeal and pharyngeal-laryngeal lipomas. Ann Otolaryngol Chir Cervicofac 2000;117:322-6

5. Persaud RAP, Kotnis R, Ong CC, Bowdler DA. A rare case of a pedunculated lipoma in the pharynx. Emerg Med J 2002;19:275-6.

6. Singhal SK, Virk RS, Mohan H, et al. Myxolipoma of the epiglottis in an adult: a case report. Ear Nose Throat J 2005;84:728, 730, 734 .

7. Fyfe B, Mittleman RE. Hypopharyngeal lipoma as a cause for sudden asphyxial death. Am J Forensic Med Pathol $1991 ; 12: 82-4$

8. Landinez-Cepada GA, Alarcos-Tamayo EV, Millás-Gómez T, Morais-Pérez D. Laryngeal lipoma associated with Madelung,s disease: a case report. Acta Otorrhinolaryngol Esp. 2012 63(4):311-3.

9. Lucas RB. Tumors of adipose tissue. In: Lucas RB, editor. Pathology of tumors of oral tissue. Fourth edition. London: Churchill-Livingstone; 1984. p. 176-9.

10. Wenig BM. Lipomas of the larynx and hypopharynx: a review of the literature with the addition of three new cases. J Laryngol Otol 1995;109:353-7.

11. Miettinen MM, Mandahl N. Spindle cell lipoma/pleomorphic lipoma. In: Fletcher C.D.M, Unni K.K., Mertens F. (eds): World Health Organization Classification of Tumours. World Health Classification of Tumours International Agency For Research of Cancer (IARC) Pathology and Genetics of Tumours of Soft Tissue and Bone., Lyon: IARC Press; 2002. p. 31-32.

12. Becker M, Burkhardt K, Dulgerov P, Allal A. Imaging of the larynx and hypopharynx. Eur J Radiol 2008;66(3):460-79.

MATERIA MEDICA • Vol. 33・ No. 1 • januar 2017. 
13. De Vicentiis M, Greco A, Mascelli A, Soldo P, Zambetti G. Lipoma of the larynx: a case report. Acta Otorhinolaryngol Ital. 2010;30(1):58-63.

14. Esclamado RM, Disher MJ, Ditto JL, Rontal E, McClatchey KD. Laryngeal liposarcoma. Arch Otolaryngol Head Neck Surg 1994;120:422-6.

Author for correspondence: Milan B. Jovanovic, Clinic of Otorhinolaryngology with Maxillofacial Surgery, Clinical Hospital Center Zemun, Vukova 9, 11080, Zemun, Serbia e-mail: majov@eunet.rs Tel.: +381-11-3291851 